\title{
Oceanographic conditions associated with white shark (Carcharodon carcharias) habitat use along eastern Australia
}

\author{
K. A. Lee ${ }^{1,2, *}$, P. A. Butcher ${ }^{3}$, R. G. Harcourt ${ }^{2}$, T. A. Patterson ${ }^{4}$, V. M. Peddemors ${ }^{5}$, \\ M. Roughan ${ }^{6}$, D. Harasti $^{7}$, A. F. Smoothey ${ }^{5}$, R. W. Bradford ${ }^{4}$ \\ ${ }^{1}$ Sydney Institute of Marine Science, Mosman, NSW 2088, Australia \\ ${ }^{2}$ Biological Sciences, Macquarie University, Sydney, NSW 2109, Australia \\ ${ }^{3}$ NSW Department of Primary Industries, National Marine Science Centre, Coffs Harbour, NSW 2450, Australia \\ ${ }^{4}$ Commonwealth Scientific and Industrial Research Organisation (CSIRO), Hobart, TAS 7001, Australia \\ ${ }^{5}$ NSW Department of Primary Industries, Sydney Institute of Marine Science, Mosman, Sydney, NSW 2088, Australia \\ ${ }^{6}$ School of Mathematics and Statistics, UNSW Sydney, NSW 2052, Australia \\ ${ }^{7}$ NSW Department of Primary Industries, Nelson Bay, NSW 2315, Australia
}

\begin{abstract}
Management of species with wide-ranging migrations is a complex issue, made more challenging when the species is both protected and poses a risk to humans. Understanding the oceanic conditions associated with shark habitat use can help develop mitigation strategies or warning systems that meet both conservation and human safety objectives. Using satellite tracks from 77 juvenile and sub-adult white sharks tagged over $10 \mathrm{yr}$, we modelled individual movement patterns using hidden Markov models and applied generalised additive (mixed) models to explore correlations between movement patterns (presence-absence, habitat selection and behavioural state) and oceanographic and bathymetric variables. White sharks used the whole of the continental shelf, down to depths of $350 \mathrm{~m}$ on the continental slope. Sharks were present over a wide range of sea surface temperatures (SSTs; $10-27^{\circ} \mathrm{C}$ ), with the highest probability of occurring at $\sim 20^{\circ} \mathrm{C}$. However, the number of average daily tag positions was greatest when SST was between 14 and $18^{\circ} \mathrm{C}$, and sharks were more likely to exhibit area-restricted movement when SST was between $\sim 19$ and $23^{\circ} \mathrm{C}$. Sharks were more likely to be present and selected habitats in productive areas with moderate to high surface chl a concentrations as well as thermal and productivity fronts. Although mesoscale eddies did not influence the likelihood of individuals being present in an area, there was a higher density of sharks in cold-core eddies compared to warm-core eddies. This study indicates that white shark presence and dispersal may be linked, perhaps via prey distribution, to oceanic conditions, potentially assisting development of suitable shark bite mitigation strategies.
\end{abstract}

KEY WORDS: Carcharodon carcharias $\cdot \mathrm{Chl} a \cdot$ Generalised additive mixed models $\cdot$ Habitat use Satellite tracking $\cdot$ Sea surface temperature

\section{INTRODUCTION}

Apex predators are vital to the health of the marine environment, and their removal can result in topdown effects that cascade through the trophic levels (Heithaus et al. 2008, Baum \& Worm 2009, Ferretti et al. 2010). However, managing wide-ranging species, especially those that span several national or interna-

*Corresponding author: kate.asha.lee@gmail.com

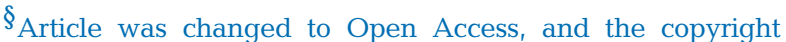
notice updated after publication.

This corrected version: February 9, 2021 tional jurisdictions, is a complex issue. This is made even more challenging for species that may pose a risk to humans, such as sharks, where the risk has to be mitigated while still achieving management and/or conservation targets (Ferretti et al. 2015). Understanding the ecology of these species, in particular the environmental variables associated with their movement and habitat selection, is essential to

( ) The authors 2021. Open Access under Creative Commons by Attribution Licence. Use, distribution and reproduction are unrestricted. Authors and original publication must be credited.

Publisher: Inter-Research · www.int-res.com 
developing effective management practices that can meet both purposes (Ryan et al. 2019, White et al. 2019).

In Australia, 3 species of sharks (white shark Carcharodon carcharias, tiger shark Galeocerdo cuvier and bull shark Carcharhinus leucas) account for the majority of serious or fatal shark attacks on humans (West 2011, Mcphee 2014). Of the 3 species, white sharks have the widest distribution, ranging from Papua New Guinea to sub-Antarctic Islands (Bradford et al. 2020, Spaet et al. 2020), and have been responsible for the largest number of human deaths and injuries. The abundance of adult white sharks has remained relatively stable up to 2018 following protection (classified as Vulnerable, IUCN; Rigby et al. 2019) that was put in place in the 1990s (Hillary et al. 2018). Effective conservation efforts, however, should see an increase in white shark abundance over time. It remains to be seen how increases in human water usage, variation in shark behaviour and any change to the density of sharks in areas heavily utilised during human water activities lead to more or fewer human-shark interactions. Either way, to establish a baseline picture of shark movements from which we may judge the degree of future change requires interrogation of data from long-term tracking studies. These have already given us unprecedented insights into the range of movements displayed by white sharks, from repeated returns to specific locations (Bruce \& Bradford 2012, Kock et al. 2013, Curtis et al. 2018) to continental- (McAuley et al. 2017) and transoceanic-scale migrations (Bonfil et al. 2005, Weng et al. 2007a, Domeier \& Nasby-Lucas 2008, Duffy et al. 2012).

While characterised by these largescale individual movements, several discrete populations exist throughout their global distribution (Pardini et al. 2001, Jorgensen et al. 2010, Gubili et al. 2012). In the Australasian region, genetic analyses have revealed that there are 2 white shark populations, south-western and eastern coastal populations (Blower et al. 2012). There is an approximate demarcation between the south-western and eastern populations from around Wilsons Promontory in Bass Strait (Fig. 1) to approximately $142^{\circ} \mathrm{E}$ (see Spaet et al. 2020). Both of these populations are genetically distinct from the South African population (Pardini et al. 2001). This divergence within the Australasian region has been corroborated using satellite tracking, which has revealed sharks moving between the east coast of Australia and New Zealand, New Caledonia and Papua New Guinea (Bruce \& Bradford 2012, Duffy et al. 2012, Francis et al. 2015) but only limited movement between eastern and western Australia (McAuley et al. 2017, Bruce et al. 2019).

Traditional mark-recapture methods have been unable to provide an accurate estimate of white shark population trajectories (Braccini et al. 2017) or demonstrate the efficacy of existing conservation measures. However, using a new mark-recapture framework, based on genetic relatedness (close-kin mark-recapture), Hillary et al. (2018) provided the first estimate of abundance for the eastern Australasian white shark population ( 2500-6750), inclu-

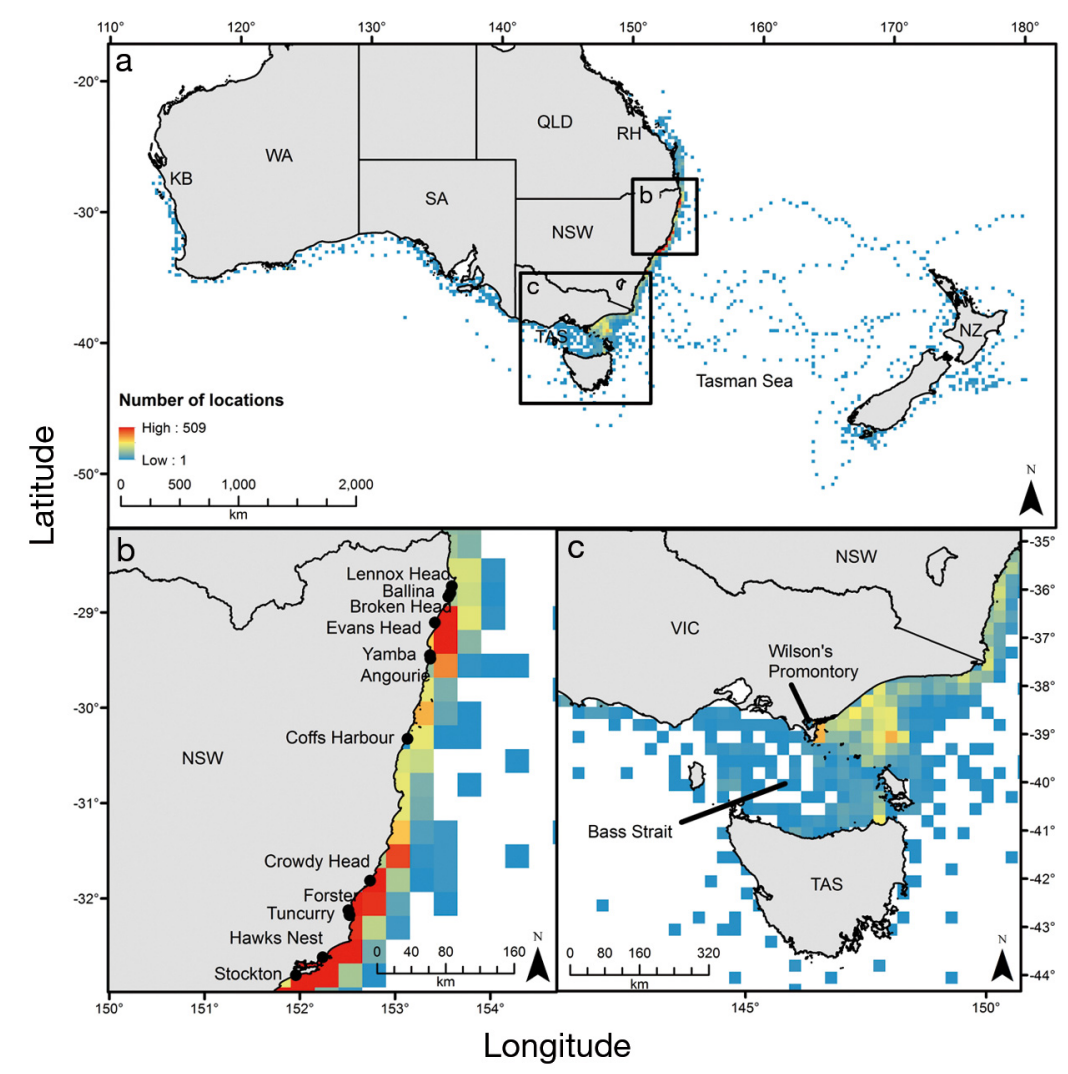

Fig. 1. Number of locations from 77 satellite-tagged white sharks tracked from 2007 to 2017 (a) in Australia and New Zealand (NZ), (b) along the New South Wales (NSW) coast where sharks were tagged and (c) in Bass Strait, showing limited movement west of the strait. QLD: Queensland; SA: South Australia; WA: Western Australia; VIC: Victoria; TAS: Tasmania. The northernmost extent of white shark distribution on the east and west coasts as shown with local town names: $\mathrm{RH}=$ Rockhampton and $\mathrm{KB}=$ Kalbarri. Maps were generated in ArcGIS 10.5 
ding survival rates for both adults (>90\%) and juveniles $(73 \%)$. Despite the relatively high survival rates and having been protected in Australian waters since the mid-1990s, the abundance of the eastern Australasian white shark population has remained stable (Hillary et al. 2018, Davenport et al. 2020). Accidental and illegal by-catch by commercial and recreational fishers continues to threaten white sharks throughout Australian waters, with the eastern Australasian population further subjected to a range of lethal and non-lethal shark control activities in New South Wales (NSW; first implemented in 1937) (Lee et al. 2018a, Tate et al. 2020) and Queensland (Department of Sustainability 2013). Juvenile $(<3 \mathrm{~m})$ white sharks predominately use continental shelf waters (Bruce \& Bradford 2012, Curtis et al. 2018, Bruce et al. 2019), shifting to pelagic habitats as they grow (Skomal et al. 2017). This makes juveniles and sub-adults more vulnerable to human-based activities than adults, as evidenced by their lower (albeit relatively high for an apex predator) survival rates (Hillary et al. 2018) and prevalence in the NSW Shark Meshing Program (Reid et al. 2011).

Predicting the distribution of top predators that are able to span a large range of oceanic conditions (Spaet et al. 2020) is challenging, as sharks most likely rely on evolved migration strategies and distribute at fine scales according to local distribution of prey resources. However, there has been little examination of the regional distribution of white sharks in eastern Australian waters in relation to ocean conditions (e.g. surface temperature and chlorophyll concentration), which, by being a proxy for influences on lower trophic levels, may predict distribution of white sharks (Huveneers et al. 2018). Improved understanding of the correlations between oceanographic conditions associated with juvenile white shark occurrence, habitat selection and movement patterns may help inform the framing of policy regarding non-lethal shark bite mitigation strategies (e.g. drones, shark management alert in real-time [SMART] drumline deployments, shark spotters, aerial surveillance). Effective mitigation strategies, in turn, could lead to a reduction in human-induced mortalities and improved conservation outcomes for white sharks.

Accordingly, using a 10 yr (2007-2017) satellite tracking dataset from 77 juvenile and sub-adult white sharks tagged in eastern Australian waters, we (1) show the relative influence of oceanographic and physical variables on shark occurrence and relative density and (2) identify environmental drivers of individual shark behaviour along eastern Australia.

\section{MATERIALS AND METHODS}

\subsection{Tagging and track processing}

White sharks were tagged at 10 locations in eastern Australia (Fig. 1b) between October 2007 and November 2017 (see Table 2). Capture and tagging followed methods described in Bruce \& Bradford (2012) and Harasti et al. (2017), wherein sharks were either (1) visually located from a vessel or helicopter before being presented with a baited hook from a vessel or (2) caught on monitored surface-buoyed setlines. Once captured, the sharks were restrained alongside the vessel or held in an in-water stretcher for tagging. Satellite-linked radio tags (hereafter referred to as tags) were attached to their first dorsal fin. Two models of tags were used: Wildlife Computers ${ }^{\odot}$ SPOT and SPLASH tags. Transmissions from the tags were extracted from the ARGOS collection and location system (www.argos-system.org/). The location accuracy of both tag models is determined by the timing and number of transmissions received by ARGOS satellites during a single pass (Hays et al. 2001, Hazel 2009). Accuracy of the location estimate is presented as location class (LC) 3, 2, 1, 0, A, B and Z, with LC3 providing the lowest error (predicted RMS $\leq 250 \mathrm{~m}$ ), LCB the highest (predicted RMS > $1500 \mathrm{~m}$ ) and LCZ indicating invalid positions. All LCZ locations were removed from subsequent analyses.

Accepted positions used for the analyses were obtained using the methods described in Bruce et al. (2006), whereby all positions with LC3, 2 and 1 were accepted, and LC0, A and B were only accepted if their location relative to a reliable previous location was within a feasible swimming distance (based on a swimming speed of $4 \mathrm{~km} \mathrm{~h}^{-1}$ ) in the time period between transmissions. To ensure statistical power, all sharks that were tracked for less than or equal to the $5^{\text {th }}$ percentile $(9 \mathrm{~d})$ were removed from subsequent analyses (4 sharks). There was also a natural cut-off at $9 \mathrm{~d}$, with the remaining sharks being tracked from $12+\mathrm{d}$.

Locations can only be calculated when a shark is at the surface, allowing communication with the ARGOS satellite constellation. Track reconstructions used all available data; however, temporal gaps occur where light-based data are unavailable, and SPOT and SPLASH tags do not collect light-based data to inform periods when the tag has not transmitted. Therefore, there is high variability in the number of location estimates due to each shark's surfacing behaviour (Lea et al. 2015, 2018). To avoid bias in the amount of time a shark spent in a given area, we fol- 
lowed the methods of Bruce et al. (2019), calculating an average daily position for each shark and using linear interpolation to normalise the frequency of locations by generating points at $24 \mathrm{~h}$ intervals along tracks with gaps of $\leq 5 \mathrm{~d}$. Tracks with gaps of $>5 \mathrm{~d}$ were split into separate sections.

Average daily positions (ADPs) were weighted by track duration, thereby reducing bias from high coverage closer to tagging locations. Following the methods outlined in Block et al. (2011), each ADP was weighted by the inverse number of sharks with locations on the same relative tracking day, up to the $85^{\text {th }}$ percentile of all track lengths (382 d), beyond which the weights were set equal to that obtained on the $382^{\text {nd }}$ day (the threshold day).

\subsection{Oceanographic and physical data}

The spatial and temporal resolutions of each remotely sensed variable are described below and summarised in Table 1. Daily remotely sensed sea surface temperature (SST) and chl a data were downloaded from the Integrated Marine Observing System (IMOS) ocean data portal (AODN; https:// portal.aodn.org.au) (IMOS 2017).

Cloud cover or opacity of coastal waters due to turbulence in nearshore areas can cause gaps in remotely sensed data at fine spatial and temporal scales. Lee et al. (2018b) showed that by using known de-correlation length and time scales of SST, the number of days that satellite data were usable for a particular location could be increased, while still obtaining similar accuracy to values extracted from a single pixel. Therefore, to obtain finer-scale SST values, we used the average SST from all pixels within distances of $8 \mathrm{~km}$ across-shelf and $20 \mathrm{~km}$ along-shelf to average the satellite SST values. These distances are within known de-correlation distances (Schaeffer et al. 2016) and had the highest correlations overall for this part of the coast (Lee et al. 2018b). A $3 \mathrm{~d}$ rolling mean, centred on the day of interest, was applied to the area-averaged SST data to interpolate the values for days when no satellite data were available (due to cloud cover). Similarly, distances of $4 \mathrm{~km}$ across-shelf and $6 \mathrm{~km}$ along-shelf were used to average the chl $a$, as again these values are less than known de-correlation lengths (Schaeffer et al. 2016).

Bathymetry was obtained from the Australian Bathymetry and Topography Grid (www.ga.gov.au/ metadata-gateway/metadata/record/gcat_67703) at a spatial resolution of $0.0025^{\circ}$. This was used to indicate water depth at the animal's position and hence

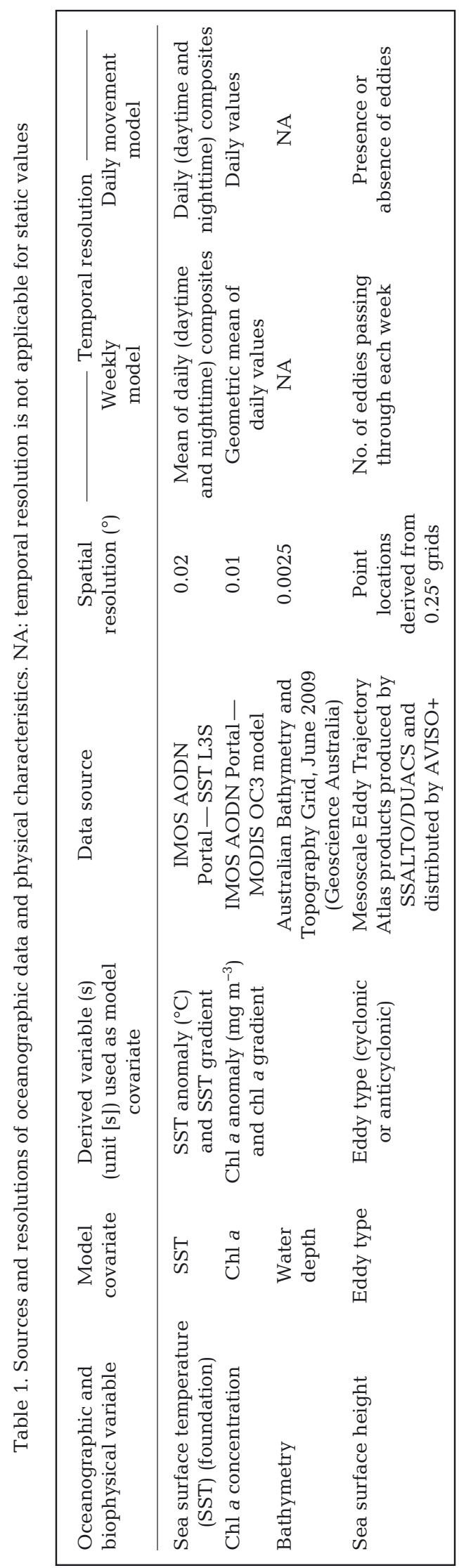


identify location across the continental shelf and slope.

A global dataset tracking mesoscale eddies (called the Mesoscale Eddy Trajectory Atlas) was downloaded from Archiving, Validation and Interpretation of Satellite Oceanographic data (AVISO+; www.aviso. altimetry.fr/es/data/products/value-added-products/ global-mesoscale-eddy-trajectory-product.html). The Mesoscale Eddy Trajectory Atlas uses a modified version of the algorithm used by Chelton et al. (2011) to identify and track eddies (Schlax \& Chelton 2016) from global sea surface height data (Pujol et al. 2016). We classified the core of each eddy within our study (spatial and temporal) using definitions given in Gaube et al. (2018).

Weekly means of each environmental variable were calculated for $0.25^{\circ} \times 0.25^{\circ}$ grids. The geometric mean was used for chl a due to its log-normal distribution, which is common in continental shelf waters (Mouw \& Yoder 2005, Everett et al. 2014). Chl a was included as a measure of primary productivity in the absence of prey distribution data. Eddy type was summarised by calculating the total number of anticyclonic eddies, cyclonic eddies, both or neither that had passed through a grid cell in that week. Mesoscale eddy data were only available until 5 January 2017; therefore, all dates after 6 January 2017 were categorised as 'unknown' eddy type. Rapid changes in SST or chl a indicative of frontal features will be reflected in steep gradients in the underlying fields (i.e. thermal or primary productivity fronts). Both SST and chl a fronts can be associated with different water masses and are important for wide-ranging marine predators (reviewed by Scales et al. 2014 and Polovina et al. 2017) We therefore included gradient of SST and chl a calculated as the absolute difference between maximum and minimum values within each $0.25^{\circ} \times 0.25^{\circ}$ grid cell (Lea et al. 2018)

\subsection{Population-level habitat use}

Weighted locations were summed with $0.25^{\circ} \times$ $0.25^{\circ}$ grid cells to provide the relative habitat selection of white sharks along the east coast of Australia. A $0.25^{\circ} \times 0.25^{\circ}$ grid was used, as it was the resolution of the coarsest oceanographic variable (sea surface height used to derive eddies; Table 1) and greater than the location error associated with the least accurate location class (LCB $\sim 10 \mathrm{~km}$; Hays et al. 2001, Costa et al. 2010). A 2-model approach, using generalised additive models (GAMs), was used to determine if white shark habitat selection was influenced by oceanographic and physical variables. First, a binary presence-absence model was used to determine the occurrence of white sharks across the study region. Second, all grid cells where the weighted number of (summed) locations was greater than zero were used to assess the biophysical correlates of relative habitat selection.

\subsubsection{Occurrence (presence-absence) models}

All cells with a relative density $>0$ were coded as 'presence' locations. Barbet-Massin et al. (2012) showed that GAM models with 10000 randomly sampled pseudo-absence points and modelled with an equal weight for presences and absences produced the most accurate results. Likewise, pseudoabsence sampling from too restrictive or too broad geographic ranges (in relation to the presence points) can produce spurious models (VanDerWal et al. 2009). Ninety-five percent of shark ADPs were east of $142^{\circ}$ E (see Section 3 and Fig. 2) and at locations with water depths $\leq 350 \mathrm{~m}$. Therefore, to ensure that pseudo-absences were sampled from a geographic range encompassing the movement of the majority of sharks, we generated a grid matching the resolution of the weighted locations $\left(0.25^{\circ} \times 0.25^{\circ}\right)$, with $142^{\circ} \mathrm{E}$ as the westerly extent, the $\leq 350 \mathrm{~m}$ isobath as the easterly and the northern and southern extents defined by the weighted locations (Fig. 2). All cells on land were then removed. From this grid, 10000 pseudo-absences were randomly sampled with weeks and years that matched the temporal extent of the presence data but did not include any non-zero density cells.

These were modelled against weekly mean bathymetry, SD of bathymetry (as a measure of bathymetric rugosity; Scales et al. 2017), SST, SST gradient, $\mathrm{chl} a$, chl a gradient and eddy type using the 'mgcv' package (Wood 2006, 2011) in R (v3.5.0, R Core Team 2018) using a complementary log-log link function. Year and week were treated as a random effect, with each unique combination of year and week corresponding to a separate intercept. The inclusion of each of the explanatory variables was assessed using Akaike's information criterion for small sample sizes (AICc; 'MuMIn' package for $\mathrm{R}_{i}$ Bartoń 2016). The 'concurvity' function in the 'mgcv' package was used to ensure that there was no concurvity (the GAM equivalent of collinearity) between the explanatory variables. Model adequacy was checked using standard residual plots as well as auto-correlation function plots and semi-variogram plots to check for un- 


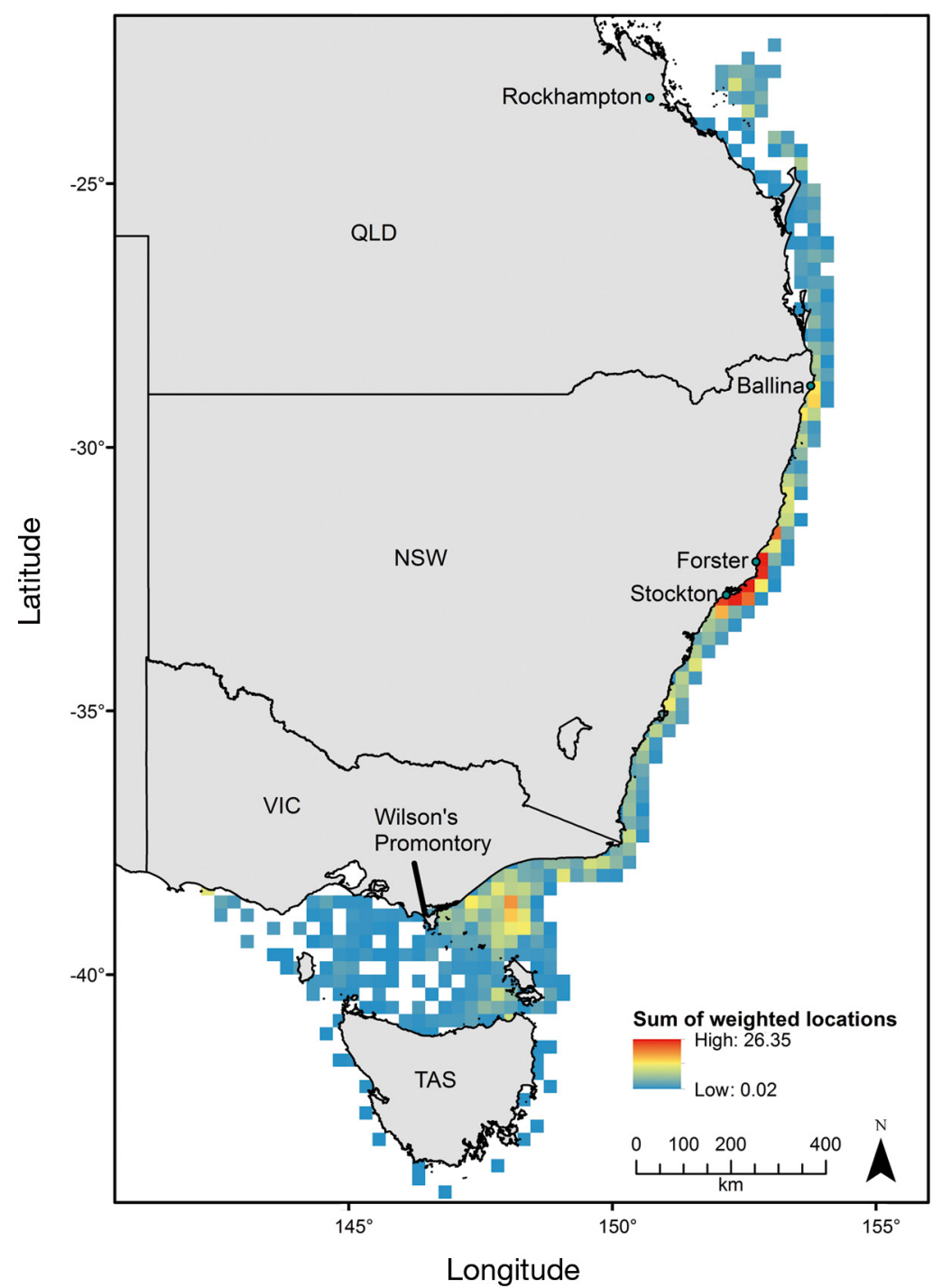

Fig. 2. Weighted locations summed in each $0.25^{\circ} \times 0.25^{\circ}$ grid cell to show the overall occupancy across the study extent from 2007 to 2017 . Locations were weighted to remove bias towards the tagging locations and tracking duration of each shark. QLD: Queensland; NSW: New South Wales; VIC: Victoria; TAS: Tasmania. Map was generated in ArcGIS 10.5

modelled spatial and temporal correlation. Model predictive error was assessed using $k$-fold cross-validation, with the data split and randomly sampled into training ( $75 \%$ of total data) and testing $(25 \%)$ data frames over each of the 5 folds and the mean area under the receiver operating characteristic curve (AUC) used as the model diagnostic. Post hoc multiple comparison (Wald) tests were conducted for any multi-level factor variable (e.g. eddy type), using the 'wald_gam' function in the 'itsadug' package (Van Rij et al. 2017), to determine the pairwise significance of each level.
2.3.2. Habitat selection

(sum of weighted locations) model

All grids cells with a sum of (weighted) locations greater than zero were modelled against the same environmental variables and with the same random effects as the presence-absence data using a Poisson-Tweedie link function. $k$-fold cross-validation was used to assess the predictive error, with RMSE and average error as the model diagnostics (Potts \& Elith 2006). The same methods as described above were used to assess model adequacy and inclusion of explanatory variables.

\subsection{Individual-level movement patterns}

Each ADP was categorised into either travelling or area-restricted behaviour using the methods described in Bruce et al. (2019). Briefly, hidden Markov models (HMMs) implemented using the 'moveHMM' (Michelot et al. 2015) R package used the turning angle and distance between successive locations to categorise the behaviour. Arearestricted movement was characterised by high turning angles and short distances between successive locations, while travelling was defined by low turning angles and larger distances between locations. The behavioural state was coded as a binary variable ( 0 is travelling; 1 is area restricted) and matched to the corresponding bathymetry and daily environmental variables. This was modelled against bathymetry, SST, SST gradient, chl $a$, chl a gradient, eddy type, sex and total length (TL) using a generalised additive mixed model with a logit link and the unique shark identity number as a random effect. The weights of each location (the inverse of the number of sharks also detected on that relative tracking day, as calculated above) were used as an offset in the model to account for the spatial bias towards tagging locations. The same model adequacy, variable selection and assessment of predictive accuracy were conducted as described above. 


\section{RESULTS}

Seventy-seven sharks (mean \pm SD: $250 \pm 41 \mathrm{~cm} \mathrm{TL}$, range: $170-367 \mathrm{~cm}$ TL) were tagged between 2007 and 2017 and tracked for $\geq 10 \mathrm{~d}$ (Table 2, Fig. 1a). Of those sharks, $4 \%$ were young of the year $(\leq 1.75 \mathrm{~m}$; Bruce \& Bradford 2012), $86 \%$ were juveniles $(>1.75$ and $<3 \mathrm{~m} \mathrm{TL}$ ) and the remaining $10 \%$ were sub-adult (>3 m TL; Table 2); $57 \%$ were female (Table 2). Sharks were tracked for an average of $71 \mathrm{~d}$ (range: 11-401 d; Table 2). Six sharks travelled across the Tasman Sea to New Zealand, and 4 sharks moved west of Bass Strait, with 1 shark moving as far as Kalbarri in Western Australia before returning to the east coast of Australia (Fig. 1a). Overall occupancy was highest between Port Macquarie and Stockton on the mid-north NSW coast, with secondary areas in northern NSW (near Ballina) and south-eastern Victoria (east of Wilsons Promontory; Fig. 2). Occupancy was higher on the continental shelf than in areas further offshore (Fig. 2). For more in-depth information about the tracking of these sharks, refer to Bruce \& Bradford 2012, Bruce et al. 2019 or Spaet et al. 2020, and refer to Table 2 for which sharks were included in these previous publications.

\subsection{Population-level habitat use}

\subsubsection{Occurrence (presence-absence) models}

Presence of white sharks was influenced by water depth, SST, chl a concentration and chl a gradient (Fig. 3, Table 3). SST explained the largest amount of deviance observed, followed by water depth (Table 3 ). The probability of a shark being present was highest in waters of $~ 50$ to 130 m depth (Fig. 3a; 66\% of presence locations were within this range) and when SSTs were between 17 and $23^{\circ} \mathrm{C}(71 \%$ of presence data points were within this range), with peak presence at $\sim 20^{\circ} \mathrm{C}$ (Fig. 3b). Chl a concentration and gradient had less of an influence on the probability of a shark being present than depth or SST, with this reflected in its smaller contribution to the deviance explained (Table 3). Shark presence was highest at intermediate concentrations of chl a (Fig. 3c) and high chl a gradients (Fig. 3d). Although eddy type was included in the model, there was no statistical difference in the probability of presence between anticyclonic and cyclonic eddies or areas that had both eddy types in the same week (all Wald tests pvalues $>0.05$; Fig. $3 \mathrm{e}$ ). The model had a high predictive ability ( $k$-fold cross-validation, mean $\mathrm{AUC} \pm \mathrm{SE}=$
$0.86 \pm 0.002$ ) despite only explaining $33.6 \%$ of the variation observed in the data.

\subsubsection{Habitat selection}

(sum of weighted locations) model

Habitat selection by white sharks was influenced by water depth and to a lesser extent SD bathymetry, SST, SST gradient, chl a concentration, chl a gradient and eddy type (Fig. 4, Table 3). Conversely, eddy type explained the largest amount of deviance, followed by SST and SD bathymetry (Table 3). The highest number of shark locations was in waters on the continental gradient with depths of $\sim 250$ to $300 \mathrm{~m}$ (Fig. 4a) and in areas of bathymetric rugosity (Fig. 4b). White sharks occurred in a wide range of water temperatures but preferentially used areas with SST $<18$ or $>24^{\circ} \mathrm{C}$ (Fig. 4 c) and in areas where SST gradient was $\sim 1$ or $>4^{\circ} \mathrm{C}$ (Fig. $4 \mathrm{~d}$ ), where (logged) chl a concentration was $\sim 1 \mathrm{mg} \mathrm{m}^{-3}$ (Fig. 4e) and along productivity fronts (Fig. 4f). However, there were few data points at the extreme ranges of each of the variables, which produced larger CIs at the data extremes. The highest number of shark locations was recorded when the presence of mesoscale eddies was unknown (after 6 January 2017; Fig. 4g). During the time when mesoscale eddies were tracked, sharks used cyclonic eddies significantly more than anticyclonic eddies (Wald test p-value: 0.044 ) or areas with both eddy types in $1 \mathrm{wk}$ (Wald test p-value: 0.002 ) but no more than areas where no eddies occurred (Wald test p-value: 0.050). There was no significant difference in shark habitat selection between anticyclonic eddies and areas where neither (Wald test p-value: 0.359) or both (Wald test p-value: 0.059) occurred. RMSE showed that modelpredicted density was 0.07 of the maximum observed ( $k$-fold cross-validation, RMSE $=0.19 \pm 0.03$; max . observed $=2.67$ ) and average error was $0.002 \pm 0.001$ ( $<0.01$ of the maximum density), despite the model only explaining $26.7 \%$ of the variation observed in the data.

\subsection{Individual-level movement patterns}

HMMs showed that white sharks exhibited arearestricted movement (smaller distances between locations and higher turning angles) along the continental shelf from south-eastern Queensland to southern NSW, south-eastern Victoria and northern Tasmania, but this was limited west of Bass Strait 
Table 2. Details of tag deployments for 77 white sharks tagged along the New South Wales coast between 2007 and 2017 (Fig. 1b). All sharks were previously reported in Spaet et al. (2020) as well as in reports shown in footnotes. Date format is $\mathrm{d} / \mathrm{mo} / \mathrm{yr}$. Any discrepancies in the last date of detection between this study and previous studies were because no Z class locations were included in this study but were included where appropriate in previous publications

\begin{tabular}{|c|c|c|c|c|c|c|}
\hline $\begin{array}{l}\text { Shark } \\
\text { no. }\end{array}$ & $\begin{array}{l}\text { Date } \\
\text { tagged }\end{array}$ & $\begin{array}{l}\text { Tagging } \\
\text { location }\end{array}$ & $\begin{array}{c}\text { Total } \\
\text { length }(\mathrm{cm})\end{array}$ & Sex & $\begin{array}{c}\text { No. of days } \\
\text { shark detected }\end{array}$ & $\begin{array}{l}\text { Last date } \\
\text { detected }\end{array}$ \\
\hline 1 & $11 / 10 / 07^{a}$ & Stockton & 240 & Female & 11 & $22 / 11 / 07$ \\
\hline 2 & $11 / 10 / 07^{a}$ & Stockton & 190 & Male & 11 & $31 / 3 / 08$ \\
\hline 3 & $30 / 10 / 09^{a, b}$ & Hawks Nest & 220 & Female & 13 & $26 / 1 / 10$ \\
\hline 4 & $10 / 10 / 12^{\mathrm{b}}$ & Hawks Nest & 280 & Female & 16 & $27 / 11 / 12$ \\
\hline 5 & $27 / 10 / 10^{\mathrm{b}}$ & Hawks Nest & 220 & Female & 16 & $8 / 12 / 10$ \\
\hline 6 & $11 / 10 / 07^{a}$ & Stockton & 200 & Female & 17 & $4 / 11 / 07$ \\
\hline 7 & $28 / 10 / 08^{a, b}$ & Hawks Nest & 229 & Female & 15 & $10 / 11 / 08$ \\
\hline 8 & $29 / 10 / 09^{\mathrm{a}}$ & Hawks Nest & 230 & Male & 25 & $17 / 1 / 10$ \\
\hline 9 & $10 / 10 / 07^{a}$ & Stockton & 240 & Female & 15 & $21 / 11 / 07$ \\
\hline 10 & $28 / 10 / 09^{a}$ & Hawks Nest & 240 & Female & 19 & 9/2/10 \\
\hline 11 & $08 / 10 / 07^{a}$ & Stockton & 210 & Male & 37 & $1 / 12 / 07$ \\
\hline 12 & $25 / 10 / 11^{b}$ & Hawks Nest & 240 & Female & 29 & $10 / 12 / 11$ \\
\hline 13 & $10 / 10 / 07^{a}$ & Stockton & 260 & Male & 53 & $20 / 1 / 08$ \\
\hline 14 & $8 / 10 / 07^{a}$ & Stockton & 190 & Female & 47 & $12 / 1 / 08$ \\
\hline 15 & $25 / 10 / 11^{b}$ & Hawks Nest & 220 & Female & 57 & $28 / 2 / 12$ \\
\hline 16 & $20 / 12 / 12^{b}$ & Hawks Nest & 320 & Female & 48 & $16 / 2 / 13$ \\
\hline 17 & $27 / 10 / 10^{b}$ & Hawks Nest & 190 & Male & 58 & $4 / 2 / 11$ \\
\hline 18 & $28 / 10 / 08^{a, b}$ & Hawks Nest & 175 & Female & 57 & $26 / 5 / 09$ \\
\hline 19 & $25 / 10 / 11^{\mathrm{b}}$ & Hawks Nest & 170 & Male & 59 & $16 / 1 / 12$ \\
\hline 20 & $11 / 10 / 07^{a}$ & Stockton & 250 & Female & 63 & $30 / 12 / 07$ \\
\hline 21 & $19 / 12 / 12^{b}$ & Hawks Nest & 218 & Female & 58 & $15 / 3 / 13$ \\
\hline 22 & $28 / 10 / 09^{a}$ & Hawks Nest & 210 & Male & 67 & $10 / 2 / 10$ \\
\hline 23 & $10 / 10 / 12^{b}$ & Hawks Nest & 230 & Male & 99 & $4 / 2 / 13$ \\
\hline 24 & $14 / 12 / 10^{\mathrm{b}}$ & Hawks Nest & 280 & Female & 168 & $31 / 5 / 12$ \\
\hline 25 & $24 / 11 / 14^{\mathrm{b}}$ & Hawks Nest & 190 & Female & 122 & $15 / 5 / 15$ \\
\hline 26 & $19 / 12 / 12^{b}$ & Hawks Nest & 260 & Female & 176 & $19 / 1 / 14$ \\
\hline 27 & $24 / 11 / 14^{\mathrm{b}}$ & Hawks Nest & 270 & Female & 158 & $10 / 6 / 15$ \\
\hline 28 & $04 / 07 / 16$ & Ballina & 268 & Female & 35 & $20 / 11 / 17$ \\
\hline 29 & $28 / 08 / 15$ & Ballina & 300 & Female & 14 & $18 / 4 / 16$ \\
\hline 30 & 02/6/16 & Evans Head & 280 & Female & 22 & $14 / 8 / 16$ \\
\hline 31 & $02 / 8 / 16$ & Coffs Harbour & 264 & Male & 19 & $1 / 9 / 16$ \\
\hline 32 & $12 / 09 / 17$ & Yamba & 242 & Female & 16 & $12 / 10 / 17$ \\
\hline 33 & $22 / 07 / 16$ & Tuncurry & 290 & Female & 29 & $20 / 11 / 16$ \\
\hline 34 & $28 / 10 / 17$ & Ballina & 306 & Male & 34 & $31 / 5 / 18$ \\
\hline 35 & $31 / 05 / 16$ & Evans Head & 265 & Male & 42 & $9 / 12 / 16$ \\
\hline 36 & 08/10/16 & Ballina & 250 & Female & 24 & $19 / 11 / 16$ \\
\hline 37 & $31 / 05 / 16$ & Evans Head & 245 & Male & 32 & $15 / 9 / 17$ \\
\hline 38 & $12 / 09 / 15$ & Broken Head & 295 & Female & 25 & $11 / 11 / 15$ \\
\hline 39 & $13 / 10 / 15$ & Ballina & 290 & Female & 67 & $23 / 4 / 16$ \\
\hline 40 & $1 / 8 / 16$ & Coffs Harbour & 293 & Male & 68 & $30 / 9 / 17$ \\
\hline 41 & $30 / 5 / 17$ & Coffs Harbour & 270 & Male & 42 & $15 / 10 / 17$ \\
\hline 42 & 7/9/16 & Tuncurry & 262 & Male & 51 & $13 / 4 / 17$ \\
\hline 43 & 6/9/16 & Tuncurry & 220 & Female & 76 & $21 / 2 / 17$ \\
\hline 44 & $15 / 11 / 17$ & Crowdy Head & 250 & Male & 38 & $1 / 1 / 18$ \\
\hline 45 & $21 / 7 / 16$ & Tuncurry & 220 & Female & 60 & $9 / 5 / 17$ \\
\hline 46 & 9/8/16 & Ballina & 259 & Female & 50 & $24 / 5 / 18$ \\
\hline 47 & $1 / 10 / 16$ & Ballina & 213 & Male & 99 & $30 / 4 / 17$ \\
\hline 48 & $5 / 7 / 16$ & Ballina & 360 & Female & 51 & $17 / 1 / 17$ \\
\hline 49 & $4 / 10 / 16$ & Ballina & 367 & Female & 63 & $16 / 1 / 17$ \\
\hline 50 & $17 / 8 / 17$ & Forster & 252 & Male & 65 & $2 / 12 / 17$ \\
\hline 51 & $26 / 8 / 15$ & Ballina & 220 & Female & 38 & $6 / 11 / 15$ \\
\hline 52 & $13 / 9 / 15$ & Ballina & 225 & Female & 58 & $9 / 1 / 16$ \\
\hline 53 & 2/10/16 & Ballina & 256 & Male & 63 & $29 / 9 / 17$ \\
\hline 54 & $14 / 10 / 15$ & Ballina & 245 & Male & 59 & $18 / 2 / 16$ \\
\hline 55 & 8/10/16 & Ballina & 222 & Female & 44 & $28 / 12 / 16$ \\
\hline
\end{tabular}


Table 2. (continued)

\begin{tabular}{|c|c|c|c|c|c|c|}
\hline $\begin{array}{l}\text { Shark } \\
\text { no. }\end{array}$ & $\begin{array}{l}\text { Date } \\
\text { tagged }\end{array}$ & $\begin{array}{l}\text { Tagging } \\
\text { location }\end{array}$ & $\begin{array}{c}\text { Total } \\
\text { length }(\mathrm{cm})\end{array}$ & Sex & $\begin{array}{c}\text { No. of days } \\
\text { shark detected }\end{array}$ & $\begin{array}{l}\text { Last date } \\
\text { detected }\end{array}$ \\
\hline 56 & $17 / 10 / 15$ & Ballina & 282 & Female & 104 & $19 / 7 / 16$ \\
\hline 57 & 26/8/15 & Ballina & 220 & Female & 49 & $4 / 11 / 15$ \\
\hline 58 & $12 / 9 / 17$ & Yamba & 282 & Male & 136 & $30 / 6 / 18$ \\
\hline 59 & $6 / 10 / 16$ & Ballina & 281 & Male & 78 & $16 / 3 / 17$ \\
\hline 60 & $21 / 7 / 16$ & Tuncurry & 267 & Male & 64 & $14 / 10 / 16$ \\
\hline 61 & $30 / 8 / 15$ & Ballina & 243 & Male & 107 & $30 / 7 / 16$ \\
\hline 62 & $28 / 9 / 16$ & Ballina & 172 & Male & 134 & $2 / 5 / 17$ \\
\hline 63 & $27 / 9 / 16$ & Ballina & 291 & Male & 103 & $3 / 6 / 17$ \\
\hline 64 & $25 / 10 / 17$ & Ballina & 252 & Male & 100 & $25 / 3 / 18$ \\
\hline 65 & $2 / 10 / 16$ & Ballina & 300 & Male & 90 & $13 / 4 / 18$ \\
\hline 66 & $2 / 10 / 16$ & Ballina & 232 & Male & 80 & $31 / 3 / 17$ \\
\hline 67 & $8 / 10 / 16$ & Ballina & 213 & Female & 92 & $8 / 4 / 17$ \\
\hline 68 & 9/8/16 & Ballina & 305 & Female & 103 & $23 / 4 / 17$ \\
\hline 69 & $24 / 10 / 17$ & Forster & 303 & Male & 80 & $21 / 3 / 18$ \\
\hline 70 & 6/6/17 & Tuncurry & 251 & Female & 92 & $9 / 3 / 18$ \\
\hline 71 & $6 / 6 / 17$ & Tuncurry & 259 & Female & 103 & $26 / 2 / 18$ \\
\hline 72 & $4 / 10 / 16$ & Ballina & 223 & Female & 125 & $26 / 5 / 18$ \\
\hline 73 & $7 / 9 / 16$ & Tuncurry & 214 & Male & 153 & $17 / 7 / 17$ \\
\hline 74 & 8/9/16 & Tuncurry & 197 & Male & 151 & $10 / 10 / 17$ \\
\hline 75 & $10 / 8 / 16$ & Ballina & 350 & Female & 163 & $28 / 6 / 18$ \\
\hline 76 & $1 / 8 / 16$ & Coffs Harbour & 214 & Female & 156 & $28 / 1 / 18$ \\
\hline 77 & $5 / 7 / 16$ & Ballina & 306 & Male & 401 & $30 / 6 / 18$ \\
\hline
\end{tabular}
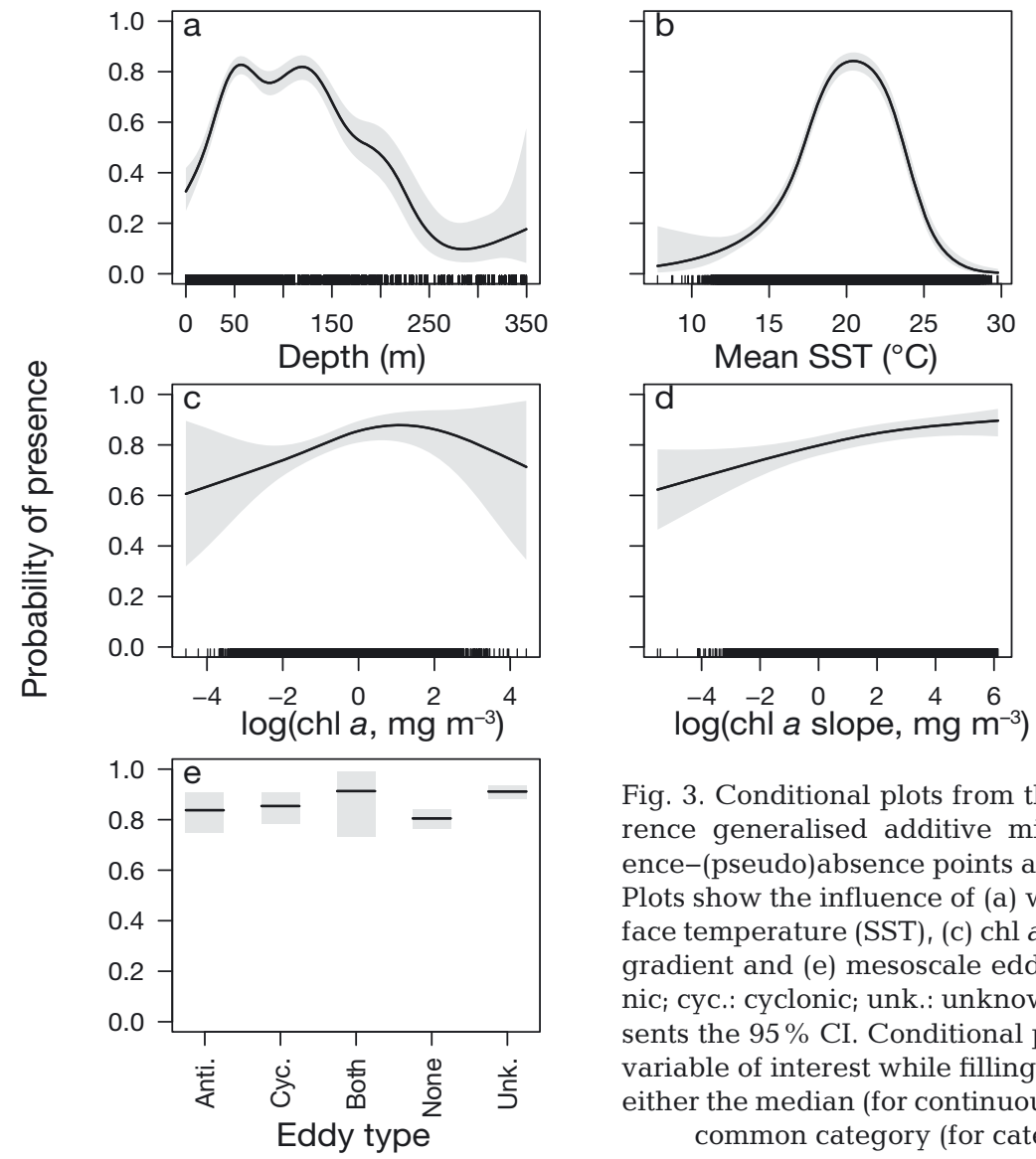

Fig. 3. Conditional plots from the weekly shark occurrence generalised additive mixed model with presence-(pseudo)absence points as the response variable. Plots show the influence of (a) water depth, (b) sea surface temperature (SST), (c) chl a concentration, (d) chl a gradient and (e) mesoscale eddy type (anti.: anticyclonic; cyc.: cyclonic; unk.: unknown). Shaded area represents the $95 \%$ CI. Conditional plots show the trend for variable of interest while filling all other variables with either the median (for continuous variables) or the most common category (for categorical variables) 
Table 3. Details showing the change in Akaike's information criterion for small sample sizes $(\Delta \mathrm{AICc})$ and deviance explained for each model variable. $\triangle$ AICc values show the difference between the reduced model (i.e. the variable was not included) and the full model (all variables included). Variables with negative $\triangle$ AICc were dropped from the final model. SST: sea surface temperature; TL: total length; - denotes where the metric is not applicable for that variable, either as it was not included in the initial models or was dropped from the final model due to a negative $\triangle \mathrm{AICC}$

\begin{tabular}{|c|c|c|c|c|c|c|}
\hline \multirow[t]{2}{*}{ Variable } & \multicolumn{2}{|c|}{ Weekly presence-absence } & \multicolumn{2}{|c|}{ Weekly relative habitat selection } & \multicolumn{2}{|c|}{ Individual-level movement patterns } \\
\hline & $\triangle \mathrm{AICC}$ & $\begin{array}{c}\text { Deviance } \\
\text { explained (\%) }\end{array}$ & $\Delta \mathrm{AICC}$ & $\begin{array}{c}\text { Deviance } \\
\text { explained (\%) }\end{array}$ & $\Delta \mathrm{AICC}$ & $\begin{array}{c}\text { Deviance } \\
\text { explained (\%) }\end{array}$ \\
\hline Depth & 148.1 & 6.5 & 25.7 & 1.6 & 195.9 & 6.7 \\
\hline SD bathymetry & -0.5 & - & 52.0 & 2.0 & - & - \\
\hline SST & 690.4 & 21.2 & 92.5 & 2.8 & 259.4 & 6.2 \\
\hline SST gradient & -0.6 & - & 31.3 & 1.5 & 12.4 & 0.3 \\
\hline Chl a & 1.7 & 1.6 & 15.9 & 1.5 & 44.4 & 4.3 \\
\hline Chl a gradient & 5.2 & 2.3 & 71.3 & 1.5 & -1.4 & - \\
\hline Eddy type & 17.6 & 1.4 & 374.5 & 11.0 & 99.6 & 3.3 \\
\hline $\mathrm{TL}$ & - & - & - & - & 82.7 & 2.2 \\
\hline Sex & - & - & - & - & 2.1 & 0.1 \\
\hline Random effects & 17.2 & 0.6 & 56.8 & 4.7 & 15.4 & 1.7 \\
\hline
\end{tabular}
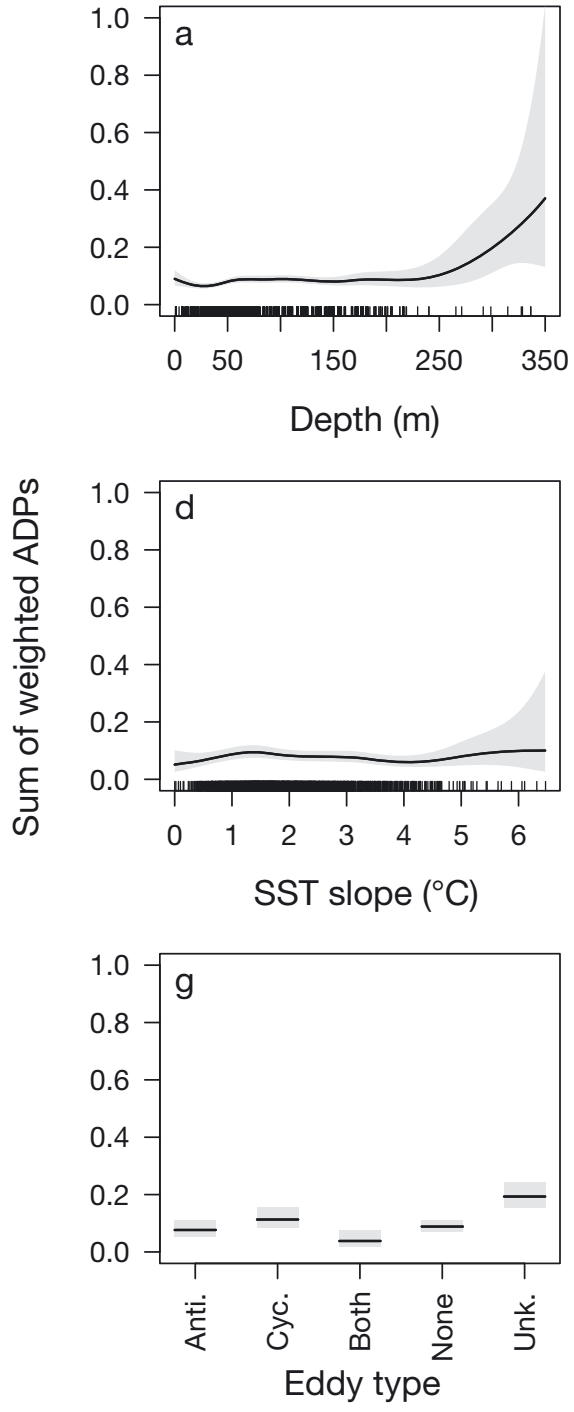
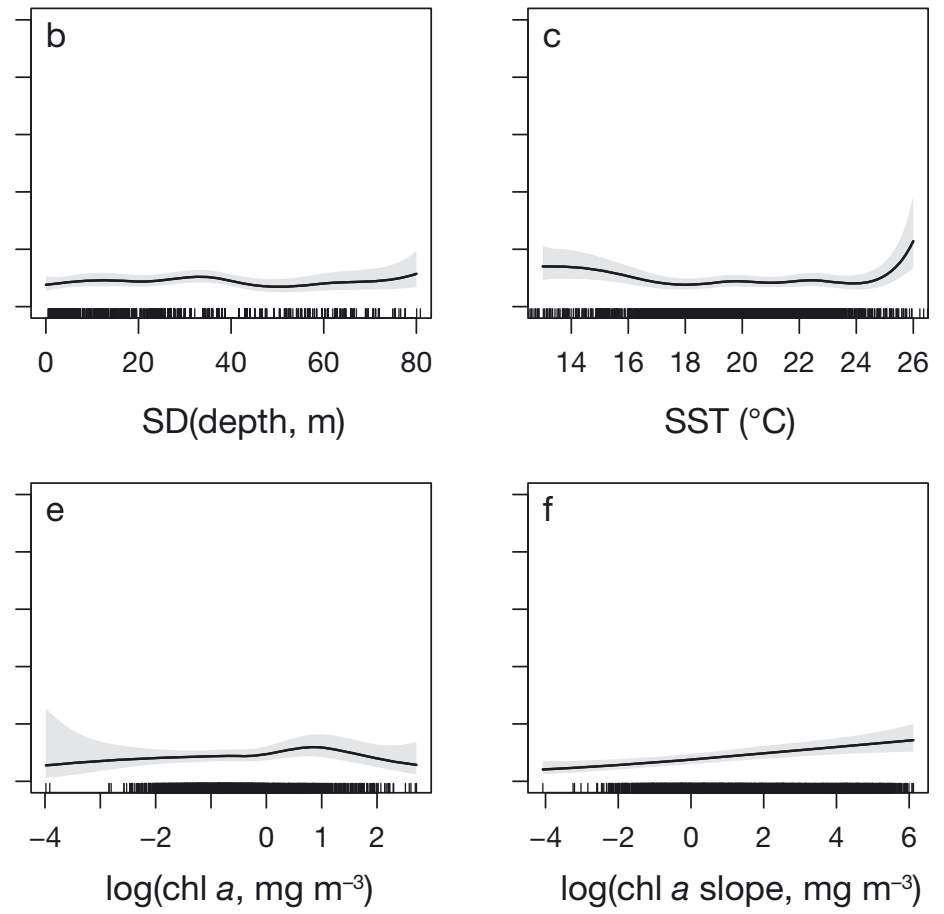

Fig. 4. Conditional plots from weekly habitat selection generalised additive mixed model that uses the total number of weighted shark locations as a response. Plots show the influence of (a) water depth, (b) bathymetric rugosity (SD of water depth), (c) sea surface temperature (SST), (d) SST gradient, (e) chl a concentration, (f) chl a gradient and (g) mesoscale eddy type (anti.: anticyclonic; cyc.: cyclonic; unk.: unknown). Shaded area represents the $95 \%$ CI. Conditional plots show the trend for variable of interest while filling all other variables with either the median (for continuous variables) or the most common category (for categorical variables). Note that the response variable, sum of weighted average daily positions (ADP), had a range of 0 to 26 ; however, these figures are displayed from 0 to 1 to allow visibility of results 
(Fig. 5). Sharks, however, displayed travelling behaviour (longer distances between consecutive locations and low turning angles) throughout the study area (Fig. 5). Movement was classified as area restricted when step lengths were an average of $8.8 \pm$ $8.5 \mathrm{~km}$ and as travelling when the step length was $63.7 \pm 59.8 \mathrm{~km}$. Sharks spent a median of 8 consecutive days displaying area-restricted movements (inter-quartile range: $4-16 \mathrm{~d}$ ). One shark spent $116 \mathrm{~d}$ exhibiting area-restricted movement off the coast of Port Stephens, well in excess of the $90^{\text {th }}$ percentile (26 d). Sharks spent a median of 4 consecutive days travelling (inter-quartile range: $2-8 \mathrm{~d}$ ). As with arearestricted movements, number of days travelling was highly variable. For example, 1 shark spent 66 consecutive days travelling from Port Stephens to northern Tasmania $\left(90^{\text {th }}\right.$ percentile $\left.=13 \mathrm{~d}\right)$.

The probability of a shark displaying area-restricted movement was influenced by water depth, SST, SST gradient, chl a concentration and eddy type (Fig. 6, Table 3). Sharks showed more area-restricted movement in shallow waters $(<60 \mathrm{~m}$ water depth) and on the continental slope at $\sim 300 \mathrm{~m}$ (Fig. 6a), when SST was between $\sim 19$ and $23^{\circ} \mathrm{C}$ (Fig. 6b), at thermal fronts with an SST gradient of $>3^{\circ} \mathrm{C}$ (Fig. 6c) and at high chl a concentrations (Fig. 6d). There was no statistical difference between anticyclonic and cyclonic eddies or areas with no eddies (all Wald test p-values $>0.05$; Fig. 6e), but there was a lower probability of a shark displaying area-restricted move-

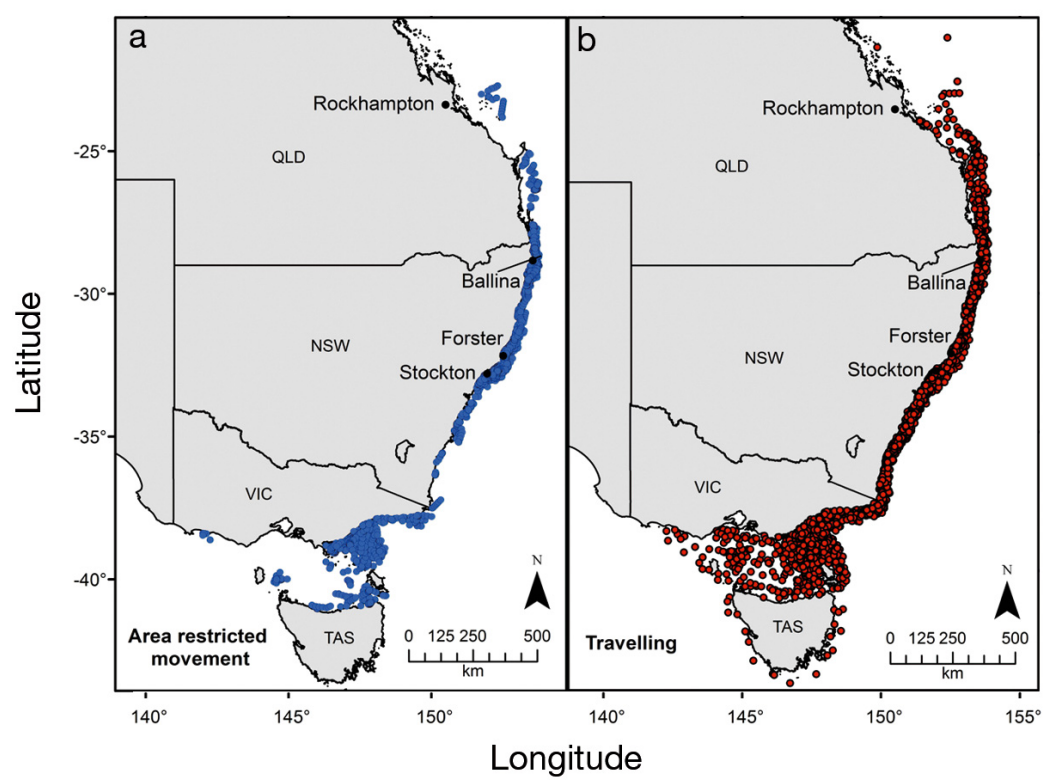

Fig. 5. (a) Area-restricted movement and (b) travelling locations estimated from hidden Markov models. QLD: Queensland; NSW: New South Wales; VIC: Victoria; TAS: Tasmania. Map was generated in ArcGIS 10.5 ment in a cyclonic eddy versus no eddy (Wald test p-value $=0.04 ;$ Fig. 6e). Sharks between $<200$ and $\sim 250 \mathrm{~cm}$ TL had the highest probabilities of showing area-restricted movement (Fig. 6f), and males had a significantly higher probability than females (Wald test $\mathrm{p}$-value $=0.04 ;$ Fig. $6 \mathrm{~g}$ ). The model had an AUC of $0.71 \pm 0.003$ and explained $24.9 \%$ of the variation observed in the data with each variable individually contributing less than $7 \%$ (Table 3 ).

\section{DISCUSSION}

Using satellite tracks from 77 white sharks, we have shown the influence that oceanographic and physical factors have on the occurrence and habitat use of juvenile and sub-adult white sharks along the east coast of Australia. The spatial extent of their movement matches previous estimates by Bruce \& Bradford (2012) and Bruce et al. (2019), which were based on a subset of the data presented here (22 and 27 sharks, respectively). However, like Spaet et al. (2020), we have quantified more extensive movement across Bass Strait than previously documented (Bruce \& Bradford 2012, 2018). Nevertheless, only 3 sharks moved into South Australian waters, and so overall their movements support the 2-population model proposed by Blower et al. (2012).

Overall occupancy was highest in 3 areas on the east coast of Australia: 2 are known nursery areas (Stockton to Forster in NSW and southeastern Victoria) previously reported by Bruce \& Bradford (2012) and Bruce et al. (2019), while a new region of high occupancy in the far north coast of NSW was identified. Corroborating this third region was the capture and tagging of $36 \%$ of sharks around Ballina. Juvenile white sharks are known to return to the 2 nursery areas, with sharks visiting the Stockton to Forster region for at least 5 consecutive years following tagging (Bruce et al. 2019). One shark included in this study displayed area-restricted movement between Stockton and Forster for 116 consecutive days. Seasonal philopatry is common in white sharks with juveniles making annual migrations to the same areas in the North Atlantic (Curtis et al. 2018), while juveniles and adults in the eastern Pacific return to the same coastal sites (Jorgensen et al. 

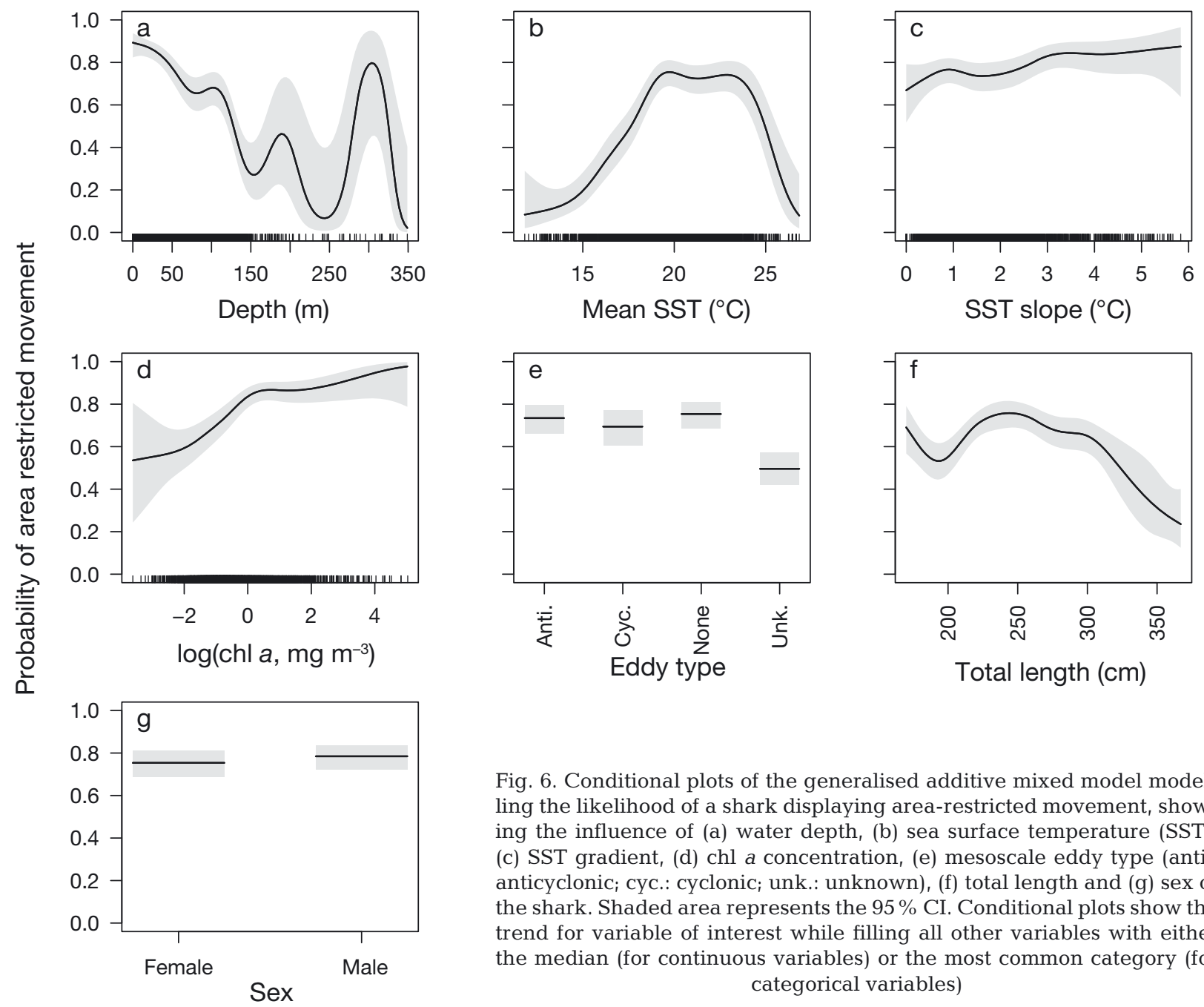

Fig. 6. Conditional plots of the generalised additive mixed model modelling the likelihood of a shark displaying area-restricted movement, showing the influence of (a) water depth, (b) sea surface temperature (SST), (c) SST gradient, (d) chl a concentration, (e) mesoscale eddy type (anti.: anticyclonic; cyc.: cyclonic; unk.: unknown), (f) total length and (g) sex of the shark. Shaded area represents the $95 \%$ CI. Conditional plots show the trend for variable of interest while filling all other variables with either the median (for continuous variables) or the most common category (for categorical variables)

2010, Domeier \& Domeier 2012) and islands (Domeier \& Nasby-Lucas 2007, Weng et al. 2007a).

We found $95 \%$ of daily satellite locations were in areas of $\leq 350 \mathrm{~m}$ water depth, corroborating previous findings that juvenile and sub-adult white sharks are largely shelf based (Weng et al. 2007b, Domeier \& Nasby-Lucas 2008, Bruce \& Bradford 2012, Domeier \& Domeier 2012, Duffy et al. 2012, Skomal et al. 2017). Our modelling indicated that sharks had the highest probability of occurring in waters of $\sim 50$ to $130 \mathrm{~m}$ depth (Fig. 3a), a slightly wider range than that reported by Bruce \& Bradford (2012) but within the margin of error in position estimates. Bruce \& Bradford (2012) hypothesised that sharks were using relic coastline structures to navigate or enhance foraging. In south-eastern Australia, such relic structures are low gradient and only have a relief of up to $\sim 5 \mathrm{~m}$ (Brooke et al. 2017), consistent with our findings that suggested bathymetric rugosity is a poor predictor of the presence of white sharks. Once pres- ent, sharks preferentially selected habitats in continental slope waters (>250 m water depth) compared to other depths (Fig. 4a). However, water depths of $>250 \mathrm{~m}$ were at the upper extreme of those observed and had few data points. Therefore, the increase in habitat selection may be an artefact from the underlying data distribution and must be interpreted with caution. High use of waters over the continental slope could indicate sharks forage in the nutrientrich slope waters. Juvenile white sharks have previously been recorded making regular slope excursions and diving to $984 \mathrm{~m}$ (Bruce \& Bradford 2012).

\subsection{Oceanographic conditions associated with white shark occurrence, habitat selection and movement patterns}

White sharks had a wide thermal niche $\left(10-27^{\circ} \mathrm{C}\right)$, with the highest probability of presence at $20^{\circ} \mathrm{C}$ 
(Fig. 3b). This estimate suggests a wider thermal range than those previously reported for populations in south-eastern Australia $\left(14-22^{\circ} \mathrm{C}_{i}\right.$ Bruce \& Bradford 2012), New Zealand $\left(10-16^{\circ} \mathrm{C}_{i}\right.$ Francis et al. 2012), the North Atlantic $\left(13-23^{\circ} \mathrm{C}_{i}\right.$ Skomal et al.

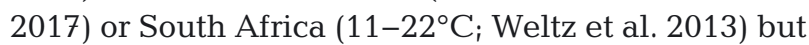
similar to adults tracked in the eastern Pacific (bimodal distribution between 10 and $26^{\circ} \mathrm{C}_{i}$ Block et al. 2011). Within this broad range, we found that the relative habitat selection of white sharks was slightly higher when SST was less than $18^{\circ} \mathrm{C}$ or higher than $24^{\circ} \mathrm{C}$ (Fig. 4C) and had a much smaller influence than in the occurrence model. This suggests that while SST is associated with the presence of white sharks, it does not strongly influence shark habitat selection. However, these SST values were at the extremes of those observed, and this pattern may be an artefact from the underlying data distribution. Nevertheless, the cooler range is consistent with catches in shark control programs in NSW and South Africa, which both showed higher white shark catches when SSTs were $\sim 17$ to $18^{\circ} \mathrm{C}$ (NSW: Lee et al. 2018a, South Africa: Wintner \& Kerwath 2018). Likewise, sightings of white sharks in South Africa increased when water temperature was higher than $14^{\circ} \mathrm{C}$ with a maximum at $18^{\circ} \mathrm{C}$ (Weltz et al. 2013). In contrast to the population-level habitat use patterns, we found that white sharks were more likely to show area-restricted movement patterns in areas with SSTs of 19 to $23^{\circ} \mathrm{C}$ (Fig. 6b). The wide thermal niche and variability in how SST influences a shark's behaviour suggests that SST may be a proxy for other environmental variables affecting white sharks (Robbins \& Booth 2012), such as productivity.

White shark occurrence and movement patterns were influenced by chl a concentration, while there was a weaker relationship between chl $a$ and habitat selection. Although the highest probability of presence and habitat selection occurred at intermediate chl a concentrations (logged chl a concentrations of $\sim 1 \mathrm{mg} \mathrm{m}{ }^{-3}$; Figs. $3 \mathrm{c} \& 4 \mathrm{e}$ ), the likelihood of a shark showing area-restricted movement patterns increased as chl a increased (Fig. 6d). The East Australian Current (EAC), the western boundary current of the South Pacific sub-tropical gyre that flows poleward along the south-eastern continental slope, strongly influences the dynamics of chl a along the east coast of Australia (Everett et al. 2014). In the northern extent of our study area (north of $31^{\circ} \mathrm{S}$ ), the EAC meanders on and off the narrow continental shelf (Archer et al. 2017), and as it encroaches on the coast, current-driven upwellings move the nutrientrich slope water into the euphotic zone (Roughan \&
Middleton 2002, 2004), resulting in higher primary productivity (Armbrecht et al. 2014, Everett et al. 2014, Rossi et al. 2014). Downstream, the EAC separates from the coast, typically at $\sim 31^{\circ}$ to $32^{\circ} \mathrm{S}$ (Cetina-Heredia et al. 2014), where the current bifurcates into the eastward-flowing Tasman Front and a southward EAC extension (Hill et al. 2011). At the separation zone, both wind- and current-driven upwellings (Roughan \& Middleton 2002, 2004, Rossi et al. 2014) result in high chl a concentrations (Everett et al. 2014). Immediately south of the separation zone, the reduced velocity of the EAC and wide shelf results in retention of enriched waters around the Stockton area (Everett et al. 2014). This region is dominated by eddies, both cyclonic and anticyclonic, that have the potential to drive onshore transport (Malan et al. 2020). Further downstream of Stockton, chl $a$ is driven by a strong seasonal cycle, with $152 \%$ increases in phytoplankton biomass each spring (Everett et al. 2014). The high productivity of the Stockton region, as well as upwellings occurring twice as often upstream of the EAC separation as downstream (Rossi et al. 2014), could explain the high occurrence of sharks in the Stockton to Port Macquarie region and off the northern NSW coast, while to the converse, low-productivity waters further south may explain the reduction in the arearestricted movement of sharks along the central and southern NSW coast (Fig. 5).

Occurrence and habitat selection increased as the chl a gradient increased (Figs. 3d \& 4f), with the latter also increasing with SST gradients of $\sim 1$ and greater than $4^{\circ} \mathrm{C}$ (Fig. $4 \mathrm{~d}$ ) despite low concurvity between chl $a$ and SST gradient in the models. As well as increasing chl a concentrations, upwellings produce chl a (Everett et al. 2014) and temperature (Schaeffer et al. 2013, Armbrecht et al. 2015, Schaeffer \& Roughan 2015) gradients in surface waters and at depth. Therefore, the relationships observed in this study could be in response to such oceanographic events. However, upwelling intensity, which is measured by the depth of the $14^{\circ} \mathrm{C}$ isotherm in this region, or sub-surface properties were not included in this study. Further research could explore how white shark spatio-temporal distributions change with sub-surface conditions. Alternatively, the relationship with chl $a$ and chl a gradient observed in this study could have been influenced by the size of the grid cells over the continental shelf and slope. Surface chl a concentrations are higher on the continental shelf (closer to the coast) and decrease offshore (Everett et al. 2014). If the sharks were in mid- to offshelf regions, the surface chlorophyll may be lower 
here than by the coast and result in chl $a$ and $\mathrm{chl} a$ gradient being included in the models.

In addition to other possible oceanographic conditions, this region is known to be eddy rich (Suthers et al. 2011, Everett et al. 2012). Anticyclonic eddies off south-eastern Australia have similar hydrodynamic properties to the EAC proper (i.e. no eddies; Baird et al. 2011), given that they are shed from the jet itself. So it makes sense that no eddy is similar to anticyclonic eddy, as observed in each of the models. Eddies are more prevalent in waters south of the EAC separation point $\left(32^{\circ} \mathrm{S}\right)$ to east of Bass Strait $\left(39^{\circ} \mathrm{S}\right)$, with cyclonic eddies having higher chl a concentrations and lower SST than surrounding waters and anticyclonic eddies having lower chl a concentrations (Everett et al. 2012) and higher SST. Therefore, the relationships observed between habitat selection and chl $a$ and SST gradient could also be influenced by their preference for cyclonic eddies. This preference for the more productive cold-core eddies is in contrast to that observed by adult white sharks in the North Atlantic, which apparently prefer warm-core, anticyclonic eddies (Gaube et al. 2018). This may highlight the relative difference in absolute temperature within eddies between the 2 locations or may highlight differing habitat selection by white sharks during different life stages.

\subsection{Implications for mitigation of human-shark interactions}

Although white sharks were less likely to occur in shallow nearshore waters (Fig. 3a), when they were present, they were more likely to exhibit short-term area-restricted movement (Fig. 6a). This, coupled with a higher probability of them displaying arearestricted movement in shallow waters (<60 m depth) with an SST of $\sim 19$ to $23^{\circ} \mathrm{C}$ and high chl a concentrations, has implications for informing measures used for shark surveillance and to minimize shark-human interactions and by-catch of white sharks in nearshore fisheries. Nearshore temperatures along the northern and central NSW coast reach 19 to $23^{\circ} \mathrm{C}$ during the late austral winter and early spring (Lee et al. 2018b), which coincides with detections from acoustically tracked sharks (Bruce et al. 2019) and higher white shark catches in the NSW Shark Meshing Program (Reid et al. 2011, Lee et al. 2018a). Smaller sharks $(<200 \mathrm{~cm} \mathrm{TL})$ had the highest probability of movements being area restricted, which has implications for managers of shark mitigation programs trying to reduce anthropogenic threats to this vulnerable age class in the nearshore regions and the likelihood of interaction with beach users (especially board riders). More than $85 \%$ of the Australian population lives within $50 \mathrm{~km}$ of the eastern seaboard of Australia (Clark \& Johnston 2017), with $45 \%$ of people along the stretch of coastline between Brisbane, Queensland, and Sydney, NSW (calculated from Australian Bureau of Statistics 2019). This stretch of coastline is the centre of the eastern Australian white shark's distribution.

The results from this study highlight the broadscale oceanographic conditions associated with juvenile white shark occurrence and habitat use. The results of this study provide previously lacking insight into the distribution of juvenile white sharks in relation to key oceanographic and bathymetric features of the region. This is important contextual information which could be used as an input into decisions on the spatial and temporal allocation of shark bite mitigation measures (e.g. drones, SMART drumlines, shark spotters, aerial surveillance) by enabling authorities to implement or enhance these measures during times when oceanographic conditions increase the potential for high nearshore densities of juvenile and sub-adult white sharks. These data will now be used to inform predictive models of shark distribution.

Acknowledgements. This project was funded and supported by the NSW Department of Primary Industries (NSW DPI; NSW Shark Management Strategy), CSIRO and the Marine Biodiversity Hub, a collaborative partnership supported through funding from the Australian Government's National Environmental Science Program (NESP). Special thanks to B. Bruce for his support and expertise throughout this project and to all staff that helped with tagging expeditions, especially C. Brand and C. Gallen (NSW DPI) for their technical expertise and dedication to field work. Tagging of sharks was approved under NSW DPI Animal Care and Ethics permits ACEC 14/07 and ACEC 07/08 and NSW DPI Scientific Collection permit P07/0099; Tasmanian DPI, Parks, Water and the Environment (DPIPWE) AEC Project 1/2013-14 (and previous derivations); DPIPWE Living Marine Resources Management Act 1995 permit 15008 (and previous derivations); DPIPWE Threatened Fauna for Scientific Purposes permit 14239; Victorian Department of Environment and Primary Industries (DEPI) Research permit 10006912; and Victorian Department of Primary Industries Protected Aquatic Biota permit PA38. SST and chl a data were sourced from IMOS (www.imos.org.au); IMOS is a national collaborative research infrastructure supported by the Australian Government. The Mesoscale Eddy Trajectory Atlas product was produced by SSALTO/DUACS and distributed by AVISO+ (www.aviso.altimetry.fr/) with support from CNES, in collaboration with Oregon State University with support from NASA. NASA is also acknowledged for the production of the remotely sensed data available through IMOS and Geoscience Australia for the bathymetry data used in this research. K.A.L. was supported by a Research Attraction and 
Acceleration Program (RAAP) from the NSW Office of Science and Research and administered through NSW State and Revenue.

\section{LITERATURE CITED}

Australian Bureau of Statistics (2019) Regional population 2018-19. www.abs.gov.au/statistics/people/population/ regional-population/2018-19

Archer MR, Roughan M, Keating SR, Schaeffer A (2017) On the variability of the East Australian Current: jet structure, meandering, and influence on shelf circulation. J Geophys Res Oceans 122:8464-8481

Armbrecht LH, Roughan M, Rossi V, Schaeffer A, Davies PL, Waite AM, Armand LK (2014) Phytoplankton composition under contrasting oceanographic conditions: upwelling and downwelling (eastern Australia). Cont Shelf Res 75:54-67

Armbrecht LH, Schaeffer A, Roughan M, Armand LK (2015) Interactions between seasonality and oceanic forcing drive the phytoplankton variability in the tropical-temperate transition zone $\left(\sim 30^{\circ} \mathrm{S}\right)$ of eastern Australia. J Mar Syst 144:92-106

Baird ME, Suthers IM, Griffin DA, Hollings B and others (2011) The effect of surface flooding on the physicalbiogeochemical dynamics of a warm-core eddy off southeast Australia. Deep Sea Res II 58: 592-605

Barbet-Massin M, Jiguet F, Albert CH, Thuiller W (2012) Selecting pseudo-absences for species distribution models: how, where and how many? Methods Ecol Evol 3:327-338

Bartoń K (2016) MuMIn: multi-model inference. R package version 1.15.6. https://CRAN.R-project.org/package=MuMIn

Baum JK, Worm B (2009) Cascading top-down effects of changing oceanic predator abundances. J Anim Ecol 78:699-714

Block BA, Jonsen ID, Jorgensen SJ, Winship AJ and others (2011) Tracking apex marine predator movements in a dynamic ocean. Nature 475:86-90

Blower DC, Pandolfi JM, Bruce BD, Gomez-Cabrera MdC, Ovenden JR (2012) Population genetics of Australian white sharks reveals fine-scale spatial structure, transoceanic dispersal events and low effective population sizes. Mar Ecol Prog Ser 455:229-244

Bonfil R, Meÿer M, Scholl MC, Johnson R and others (2005) Transoceanic migration, spatial dynamics, and population linkages of white sharks. Science 310:100-103

Braccini M, Taylor S, Bruce B, McAuley R (2017) Modelling the population trajectory of West Australian white sharks. Ecol Modell 360:363-377

Bradford R, Patterson TA, Rogers PJ, McAuley R and others (2020) Evidence of diverse movement strategies and habitat use by white sharks, Carcharodon carcharias, off southern Australia. Mar Biol 167:96

Brooke BP, Nichol SL, Huang Z, Beaman RJ (2017) Palaeoshorelines on the Australian continental shelf: morphology, sea-level relationship and applications to environmental management and archaeology. Cont Shelf Res 134:26-38

Bruce BD, Stevens JD, Malcolm H (2006) Movements and swimming behaviour of white sharks (Carcharodon carcharias) in Australian waters. Mar Biol 150:161-172

Bruce BD, Bradford RW (2012) Habitat use and spatial dynamics of juvenile white sharks, Carcharodon car- charias, in eastern Australia. In: Domeier ML (ed) Global perspectives on the biology and life history of the white shark. CRC Press, Boca Raton, FL, p 225-253

* Bruce BD, Harasti D, Lee K, Gallen C, Bradford R (2019) Broad-scale movements of juvenile white sharks Carcharodon carcharias in eastern Australia from acoustic and satellite telemetry. Mar Ecol Prog Ser 619:1-15

Cetina-Heredia P, Roughan M, van Sebille E, Coleman MA (2014) Long-term trends in the East Australian Current separation latitude and eddy driven transport. J Geophys Res Oceans 119:4351-4366

Chelton DB, Schlax MG, Samelson RM (2011) Global observations of nonlinear mesoscale eddies. Prog Oceanogr 91:167-216

Clark GF, Johnston EL (2017) Australia state of the environment 2016: coasts, independent report to the Australian Government Minister for Environment and Energy. Australian Government Department of the Environment and Energy, Canberra

Costa DP, Robinson PW, Arnould JPY, Harrison AL and others (2010) Accuracy of ARGOS locations of pinnipeds at-sea estimated using Fastloc GPS. PLOS ONE 5:e8677

* Curtis TH, Metzger G, Fischer C, McBride B and others (2018) First insights into the movements of young-of-theyear white sharks (Carcharodon carcharias) in the western North Atlantic Ocean. Sci Rep 8:10794

* Davenport D, Butcher P, Andreotti S, Matthee C, Jones A, Ovenden J (2020) Effective number of white shark (Carcharodon carcharias, Linneaus) breeders is stable over four successive years in the population adjacent to eastern Australia and New Zealand. Ecol Evol 11:186-198

Department of Sustainability Environment, Water, Population and Communities (2013) Issues paper for the white shark (Carcharodon carcharias). www.environment.gov. $\mathrm{au} /$ system/files/resources/6eb72ed4-a3fa-4604-b722a5c2b45ad1e9/files/white-shark-issues-paper.pdf

* Domeier ML, Nasby-Lucas N (2007) Annual re-sightings of photographically identified white sharks (Carcharodon carcharias) at an eastern Pacific aggregation site (Guadalupe Island, Mexico). Mar Biol 150:977-984

Womeier ML, Nasby-Lucas N (2008) Migration patterns of white sharks Carcharodon carcharias tagged at Guadalupe Island, Mexico, and identification of an eastern Pacific shared offshore foraging area. Mar Ecol Prog Ser 370:221-237

Domeier ML, Domeier M (2012) A new life-history hypothesis for white sharks, Carcharodon carcharias, in the northeastern Pacific. In: Domeier ML (ed) Global perspectives on the biology and life history of the white shark. CRC Press, Boca Raton, FL, p 199-224

Duffy C, Francis MP, Manning MJ, Bonfil R (2012) Regional population connectivity, oceanic habitat, and return migration revealed by satellite tagging of white sharks, Carcharodon carcharias, at New Zealand aggregation sites. In: Domeier ML (ed) Global perspectives on the biology and life history of the white shark. CRC Press, Boca Raton, FL, p 301-318

* Everett JD, Baird ME, Oke PR, Suthers IM (2012) An avenue of eddies: quantifying the biophysical properties of mesoscale eddies in the Tasman Sea. Geophys Res Lett 39:L16608

Everett JD, Baird ME, Roughan M, Suthers IM, Doblin MA (2014) Relative impact of seasonal and oceanographic drivers on surface chlorophyll a along a western boundary current. Prog Oceanogr 120:340-351 
Ferretti F, Worm B, Britten GL, Heithaus MR, Lotze HK (2010) Patterns and ecosystem consequences of shark declines in the ocean. Ecol Lett 13:1055-1071

* Ferretti F, Jorgensen S, Chapple TK, De Leo G, Micheli F (2015) Reconciling predator conservation with public safety. Front Ecol Environ 13:412-417

Francis MP, Duffy CA, Bonfil R, Manning MJ (2012) Vertical habitat use by white sharks, Carcharodon carcharias, in New Zealand and in oceanic and tropical waters of the Southwest Pacific Ocean. In: Domeier ML (ed) Global perspectives on the biology and life history of the white shark. CRC Press, Boca Raton, FL, p 319

Francis MP, Duffy C, Lyon W (2015) Spatial and temporal habitat use by white sharks (Carcharodon carcharias) at an aggregation site in southern New Zealand. Mar Freshw Res 66:900-918

Gaube P, Braun CD, Lawson GL, McGillicuddy DJ Jr and others (2018) Mesoscale eddies influence the movements of mature female white sharks in the Gulf Stream and Sargasso Sea. Sci Rep 8:7363

Gubili C, Duffy CA, Cliff G, Wintner SP and others (2012) Application of molecular genetics for conservation of the white shark, Carcharodon carcharias, L. 1758. In: Domeier ML (ed) Global perspectives on the biology and life history of the white shark. CRC Press, Boca Raton, FL, p 357-380

* Harasti D, Lee K, Bruce B, Gallen C, Bradford R (2017) Juvenile white sharks Carcharodon carcharias use estuarine environments in south-eastern Australia. Mar Biol 164:58

* Hays GC, Åkesson S, Godley BJ, Luschi P, Santidrian P (2001) The implications of location accuracy for the interpretation of satellite-tracking data. Anim Behav 61: 1035-1040

Hazel J (2009) Evaluation of fast-acquisition GPS in stationary tests and fine-scale tracking of green turtles. J Exp Mar Biol Ecol 374:58-68

* Heithaus MR, Frid A, Wirsing AJ, Worm B (2008) Predicting ecological consequences of marine top predator declines. Trends Ecol Evol 23:202-210

*Hill K, Rintoul S, Ridgway K, Oke P (2011) Decadal changes in the South Pacific western boundary current system revealed in observations and ocean state estimates. J Geophys Res Oceans 116:C01009

* Hillary RM, Bravington MV, Patterson TA, Grewe P and others (2018) Genetic relatedness reveals total population size of white sharks in eastern Australia and New Zealand. Sci Rep 8:2661

* Huveneers C, Apps K, Becerril-García EE, Bruce B and others (2018) Future research directions on the 'elusive' white shark. Front Mar Sci 5:108-115

IMOS (Integrated Marine Observing System) (2017) SRS Satellite - SST L3S - 01 day composite — day and night time composite. https://portal.aodn.org.au/search (accessed 1 Nov 2016, 15 Feb 2017, 24 May 2016)

* Jorgensen SJ, Reeb CA, Chapple TK, Anderson S and others (2010) Philopatry and migration of Pacific white sharks. Proc R Soc B Biol Sci 277:679-688

Kock A, O'Riain MJ, Mauff K, Meÿer M, Kotze D, Griffiths C (2013) Residency, habitat use and sexual segregation of white sharks, Carcharodon carcharias in False Bay, South Africa. PLOS ONE 8:e55048

Lea JSE, Wetherbee BM, Queiroz N, Burnie N and others (2015) Repeated, long-distance migrations by a philopatric predator targeting highly contrasting ecosystems. Sci Rep 5:11202
Lea JSE, Wetherbee BM, Sousa LL, Aming C and others (2018) Ontogenetic partial migration is associated with environmental drivers and influences fisheries interactions in a marine predator. ICES J Mar Sci 75:1383-1392

* Lee KA, Roughan M, Harcourt RG, Peddemors VM (2018a) Environmental correlates of relative abundance of potentially dangerous sharks in nearshore areas, southeastern Australia. Mar Ecol Prog Ser 599:157-179

* Lee KA, Roughan M, Malcolm HA, Otway NM (2018b) Assessing the use of area- and time-averaging based on known de-correlation scales to provide satellite derived sea surface temperatures in coastal areas. Front Mar Sci 5:261

McAuley RB, Bruce BD, Keay IS, Mountford S, Pinnell T, Whoriskey FG (2017) Broad-scale coastal movements of white sharks off Western Australia described by passive acoustic telemetry data. Mar Freshw Res 68: 1518-1531

McPhee D (2014) Unprovoked shark bites: Are they becoming more prevalent? Coast Manage 42:478-492

Michelot T, Langrock R, Patterson T, Rexstad E (2015) moveHMM: animal movement modelling using hidden Markov models. R package version 1.1. https://cran.rproject.org/package=moveHMM

* Mouw CB, Yoder JA (2005) Primary production calculations in the Mid-Atlantic Bight, including effects of phytoplankton community size structure. Limnol Oceanogr 50: 1232-1243

Pardini AT, Jones CS, Noble LR, Kreiser B and others (2001) Sex-biased dispersal of great white sharks. Nature 412:139

*Polovina JJ, Howell EA, Kobayashi DR, Seki MP (2017) The transition zone chlorophyll front updated: advances from a decade of research. Prog Oceanogr 150:79-85

* Potts JM, Elith J (2006) Comparing species abundance models. Ecol Modell 199:153-163

*Pujol MI, Faugère Y, Taburet G, Dupuy S, Pelloquin C, Ablain M, Picot N (2016) DUACS DT2014: the new multimission altimeter data set reprocessed over 20 years. Ocean Sci 12:1067-1090

R Core Team (2018) R: a language and environment for statistical computing. R Foundation for Statistical Computing, Vienna

Reid DD, Robbins WD, Peddemors VM (2011) Decadal trends in shark catches and effort from the New South Wales, Australia, shark meshing program 1950-2010. Mar Freshw Res 62:676-693

* Rigby CL, Barreto R, Carlson J, Fernando D and others (2019) White shark Carcharodon carcharias. The IUCN Red List of Threatened Species 2019: e.T3855A2878674. https://dx. doi.org/10.2305/IUCN.UK.2019-3.RLTS.T3855A2878674. en (accessed 4 June 2020)

Robbins RL, Booth DJ (2012) Seasonal sexual and size segregation of white sharks, Carcharodon carcharias, at the Neptune Islands, South Australia. In: Domeier ML (ed) Global perspectives on the biology and life history of the white shark. CRC Press, Boca Raton, FL, p 287-299

Kossi V, Schaeffer A, Wood J, Galibert G and others (2014) Seasonality of sporadic physical processes driving temperature and nutrient high-frequency variability in the coastal ocean off southeast Australia. J Geophys Res Oceans 119:445-460

* Roughan M, Middleton JH (2004) On the East Australian Current: variability, encroachment, and upwelling. J Geophys Res Oceans 109:C07003 
Ryan LA, Lynch SK, Harcourt R, Slip DJ and others (2019) Environmental predictive models for shark attacks in Australian waters. Mar Ecol Prog Ser 631:165-179

Scales KL, Miller PI, Hawkes LA, Ingram SN, Sims DW, Votier SC (2014) On the front line: frontal zones as priority at-sea conservation areas for mobile marine vertebrates. J Appl Ecol 51:1575-1583

Scales KL, Schorr GS, Hazen EL, Bograd SJ and others (2017) Should I stay or should I go? Modelling year-round habitat suitability and drivers of residency for fin whales in the California Current. Divers Distrib 23:1204-1215

Schaeffer A, Roughan M (2015) Influence of a western boundary current on shelf dynamics and upwelling from repeat glider deployments. Geophys Res Lett 42:121-128

Schaeffer A, Roughan M, Morris BD (2013) Cross-shelf dynamics in a western boundary current regime: implications for upwelling. J Phys Oceanogr 43:1042-1059

Schaeffer A, Roughan M, Jones EM, White D (2016) Physical and biogeochemical spatial scales of variability in the East Australian Current separation from shelf glider measurements. Biogeosciences 13:1967-1975

Schlax MG, Chelton DB (2016) The 'growing method' of eddy identification and tracking in two and three dimensions. Oregon State University, Corvallis, OR

Skomal GB, Braun CD, Chisholm JH, Thorrold SR (2017) Movements of the white shark Carcharodon carcharias in the North Atlantic Ocean. Mar Ecol Prog Ser 580:1-16

Tate RD, Cullis BR, Smith SDA, Kelaher BP and others (2019) The acute physiological status of white sharks (Carcharodon carcharias) exhibits minimal variation after capture on SMART drumlines. Conserv Physiol 7:coz042

Spaet JLY, Patterson, TA, Bradford RW, Butcher PA (2020) Spatiotemporal distribution patterns of immature Australasian white sharks (Carcharodon carcharias). Sci Rep 10:10169

Suthers IM, Young JW, Baird ME, Roughan M and others (2011) The strengthening East Australian Current, its eddies and biological effects - an introduction and overview. Deep Sea Res II: Top Stud Oceanogr 58: 538-546

Editorial responsibility: Elliott Hazen,

Pacific Grove, California, USA

Reviewed by: S. Andrzejaczek and 2 anonymous referees
Van Rij J, Wieling M, Baayen R, Van Rijn H (2017) itsadug: interpreting time series and autocorrelated data using GAMMs. R package version 2.3. https://cran.r-project. org/package=itsadug

*VanDerWal J, Shoo LP, Graham C, Williams SE (2009) Selecting pseudo-absence data for presence-only distribution modeling: How far should you stray from what you know? Ecol Modell 220:589-594

*Weltz K, Kock AA, Winker H, Attwood C, Sikweyiya M (2013) The influence of environmental variables on the presence of white sharks, Carcharodon carcharias at two popular Cape Town bathing beaches: a generalized additive mixed model. PLOS ONE 8:e68554

*Weng KC, Boustany AM, Pyle P, Anderson SD, Brown A, Block BA (2007a) Migration and habitat of white sharks (Carcharodon carcharias) in the eastern Pacific Ocean. Mar Biol 152:877-894

*Weng KC, O'Sullivan JB, Lowe CG, Winkler CE, Dewar H, Block BA (2007b) Movements, behavior and habitat preferences of juvenile white sharks Carcharodon carcharias in the eastern Pacific. Mar Ecol Prog Ser 338: 211-224

WWest JG (2011) Changing patterns of shark attacks in Australian waters. Mar Freshw Res 62:744-754

* White CF, Lyons K, Jorgensen SJ, O'Sullivan J, Winkler C, Weng KC, Lowe CG (2019) Quantifying habitat selection and variability in habitat suitability for juvenile white sharks. PLOS ONE 14:e0214642

Wintner SP, Kerwath SE (2018) Cold fins, murky waters and the moon: What affects shark catches in the batherprotection program of KwaZulu-Natal, South Africa? Mar Freshw Res 69:167-177

Wood SN (2006) Generalized additive models: an introduction with R. Chapman and Hall/CRC Press, Boca Raton, FL

*Wood SN (2011) Fast stable restricted maximum likelihood and marginal likelihood estimation of semiparametric generalized linear models. J R Stat Soc Ser B Stat Methodol 73:3-36

Submitted: July 26, 2020;

Accepted: November 10, 2020

Proofs received from author(s): January 20, 2021 